\title{
Post-Conflict Rehabilitation: From Aid to Development
}

\author{
Mladen Stanicic*
}

\section{Introduction}

The new European approach regarding the economic aspects of post-conflict rehabilitation (PCR) in the so-called Western Balkans was set out in the preparation documents for the EU Summit in Thessaloniki in June 2003. It stated, inter alia, that as the Western Balkan countries gradually moved from stabilization and reconstruction based on aid to association and sustainable development, policies pursuing economic and social cohesion at both the national and regional levels would become increasingly relevant. What was required was to better integrate the goal of economic and social cohesion into EU policy towards the region. There was a pressing need for new strategies to promote structural reforms across the region, including additional forms of pre-accession assistance. This would encourage states in the region to mobilize their own resources to support positive development in particularly critical areas. At the institutional level, these countries should be granted the status category of pre-accession without negotiations, which would enable them to access the pre-accession funds such as SAPARD (Special Accession Program for Agriculture and Rural Development) and ISPA (Instrument for Structural Policies for Pre-accession). In other words, these countries should be treated as pre-accession candidates without the obligation to open negotiations on membership until they were found by the Commission to be fit on their individual merits.

The region in question consists of five states-Albania, Bosnia and Herzegovina, Croatia, Macedonia, and Serbia and Montenegro - that have already joined the process of stabilization and association with the EU, together with Bulgaria and Romania. In the summit's final document, the five countries undergoing the process of stabilization and association were given the message that "the gates of Europe are open, and prospects of entering the EU are encouraging." It was said that it was expected that Bulgaria and Romania would be granted full membership by 2007. In this document, all the states were for the first time mentioned as countries within the Western Balkans region, and thus this term was officially introduced into the policies of the EU. Having in mind what had gone on in the region's tumultuous recent past, at the point the region of the Western Balkans became one of the regions where the processes of post-conflict resolution should be practiced within the new framework, tailored to new developments in the area.

The first step in this direction concerns the need to make a major change in the strategy of providing further financial cooperation or financial support to the region. The cooperation or financial support that is provided should be directed at making the region capable of independent economic development, formulated as making the tran-

* Mladen Stanicic directs the Institute for International Relations. 
sition "from aid to self-sustainability." One of the main preconditions for the implementation of this strategy is to provide these countries with access to pre-accession funds, like those provided under SAPARD or the ISPA, which would be very helpful in the process of adjusting some segments of these countries' economies to the EU criteria. For instance, the SAPARD fund is very valuable in the adjustment processes regarding agriculture. This is significant, since it is well known that agriculture is very important for the EU, as it represents a key issue in EU relations with associated member states. The ISPA fund is important for adjustment processes in the domains of transportation and ecology.

\section{The Role of Croatia}

Economic analysis shows that none of the countries in the region, not even Croatia (despite being the most advanced among them), is economically and institutionally able to finance the desired level of development from its own resources. Each of them needs foreign capital. Now the question becomes how to get it - what each of these countries should do, or what they should do together, in order to attract foreign capital, preferably in the form of foreign investments in the region. Political stability, which is a crucial precondition for post-conflict rehabilitation, is the first criterion on the list, on the basis of which the foreign investors are deciding to invest in certain areas. The importance of this criterion was magnified in the past few years. Croatia has advanced the most in this regard, followed by Macedonia. The remaining three countries have not yet started serious negotiations. That is why the Croatian contribution to the process of post-conflict rehabilitation in the region has relevance. Croatia has the biggest potential to lead the entire region along the lines of the new "from aid to self-sustainability" strategy, which is very likely to be its main contribution to the rehabilitation process in the region. Keeping in mind the fact that Croatia is expected to get official candidate status in June, it would enable the country to apply for pre-accession funds. This kind of development will enable Croatia to foster its internal stability, and thus to enhance foreign policies that will contribute to the stability of the whole region and beyond. Croatia's contribution to European security will certainly rest in its growing and constructive participation in the establishment of long-term stability in the region. Once Croatia becomes a full-fledged member of the European Union, it will act as a real producer and no longer only as a consumer of stability. Croatia will influence the states in the eastern part of the region in terms of spreading liberal democratic ideas. By meeting all the European standards and criteria, Croatia will contribute to regional security by creating a model for its eastern neighbors. That is the main contribution that Croatia can make, both to an effective and long-lasting PCR process as well as stability in the region.

The new Croatian leadership has strongly underscored its ambition to bring Croatia to full-fledged membership in the EU and NATO as soon as possible. The transfer of power after recent elections was smooth, thus proving a high level of success in democratization and institution-building. In the last two years, real GDP growth was among the highest in the transition countries, averaging above 5 percent. The forecast 
for this year is more moderate, foreseeing a gain of less than 4 percent, primarily due to the slowing down of domestic consumption. Since this category accounts for about 60 percent of the GDP structure, this will significantly affect economic growth. This underlines the main structural problem of the Croatian economy, which is that growth is mainly based on domestic consumption instead of on export. This trend complicates the problem of servicing foreign debt, which exceeds $\$ 20$ billion (or, in relative terms, more than 80 percent of GDP). This is more than is permitted by the Maastricht criteria, and the trend continues; the projected budget deficit for this year is more than 4.5 percent. In the first eleven months of the last year, the trade deficit amounted to $\$ 7.1$ billion, and the unemployment rate has been growing steadily (currently at 18.9 percent). Inflation is at its historical minimum of 1.5 percent, allowing for the lowest price increases since independence. The new government has declared that it was aware of the gravity of the structural problems in the Croatian economy, which might create an impediment to implementing structural reforms in line with the EU standards (Copenhagen criteria) and other necessary measures.

Since 1991, Croatia has been receiving European Commission assistance. Currently, the only assistance program that is in place for the five countries under the Stabilization and Association Agreement (SAA) is the CARDS (Community Assistance for Reconstruction, Development and Stabilization) program, which has built on the previous assistance programs. In turn, these were based on the ECHO and Obnova programs, which allowed for total allocations of 381.61 million euros up to 2000 . Since then, such assistance has been focused on the return of refugees and other humanitarian support efforts, which have absorbed about 90 percent of the total resources. Other allocation areas were trade, industrial standards, improvements of the labor market and investment climate, justice and home affairs, environment management, etc. The indicative financial allocations for CARDS assistance for Croatia for the period 2002-2004 are 255 million euros, which includes 113 projects in the following areas: democratic stabilization, economic and social development, justice and home affairs, administrative capacity building, and environment and natural resources. Croatia is a full participant in the SAA process, and was the only one among the SAA participants to formally apply for full-fledged membership on the basis of Article 49 of the Treaty on the EU, on 21 February 2003. After accepting this application, the EC issued a questionnaire with more than 4,500 questions on Croatia's capability to meet the Copenhagen criteria. Croatia responded to the questionnaire in October 2003, and expects positive advice from the EC very shortly.

\section{Some Strategic Issues}

The main problem that should be discussed within the process of implementation of the new economic development strategy is how to conform the assistance with development rather than to put too much stress on stabilization. This relates primarily to the CARDS assistance framework, which should prepare the countries in question for the full scope of pre-accession activities. Based on the present experience, one can recommend that, for the benefit of the post-conflict rehabilitation process, CARDS has to 
reflect the individual needs and priorities of the countries in the region, some of which are still struggling with the consequences of the conflicts in the region and have, therefore, different starting points and different absorption capacities. In this context, it is particularly important that the Commission underlines the necessity for the adjustment of Community assistance to meet individual development needs of different countries in the region, and to changes in those needs.

According to some experience, the visibility of any concerned assistance program (including CARDS) that is involved in the new assistance strategy should be enhanced, especially at the local and regional levels. In Croatia, but also in the other countries in question, NGOs in particular are concerned with the fact that only a limited number of people (apart from those directly involved) are aware of the new assistance strategy, which makes the promotion of the multitude of benefits received through the programs difficult. This is very important because the lack of visibility of any given program, and of the strategy in general, results not only in a lack of public support, but also in a lack of peer support in the institutions within which they work.

Within the scope of the new assistance strategy, additional incentives are needed in the process of the harmonization of legislation. It is very important to activate mechanisms that would secure a rapid and efficient response to the demand for expert support in the process of adjusting the national legislation to the acquis communautaire. These mechanisms should rely on the TAIEX instrument (Technical Assistance Information Exchange Office), which is now open only to the candidate countries. Such assistance should be adapted to the dynamics of legal harmonization in each recipient country on a case-by-case basis. Within the scope of implementation of the SAA after its entry into force, it is of critical importance to introduce a systematic verification of the harmonized legal provisions with the acquis communautaire by the respective services of the European Commission. This can be achieved through a screening principle.

Following the process of harmonization of national laws with the acquis communautaire, the demand for investments, which would provide for an efficient application of the harmonized legislation, will become increasingly pronounced. In that respect, and in accordance with the experience of the candidate countries, it is proposed to adjust and amend the CARDS Program in particular, in such a manner as to secure resources for investment-type projects with a view of implementing the acquis communautaire in the fields of environment protection, transport infrastructure, technical legislation, market surveillance, and the creation of infrastructure related to the functioning of the internal market in concerned countries.

Over the course of 2003, primary and secondary legislation were drafted; the year 2004 is reserved for building the capacity of the state bodies responsible for the application of the harmonized laws. 2005 is crucial in terms of the enforcement of legal provisions and building the appropriate technical infrastructure. The final deadline for the full operability of the established technical infrastructure is the beginning of 2007 . The application of technical provisions will result in a stronger demand for investments in technical infrastructure, and it will require amendments to the existing financial and technical instruments by which the Community supports the integration process of 
Croatia and other countries in the region. It will also require harmonization with the EU in such a manner that more substantial investment support is provided.

Since the CARDS Program is primarily an institution-building program, the introduction of the twinning mechanism as a model of project implementation is felt to be especially relevant. Twinning enables the direct transfer of know-how and experience from state officials in donor countries to those in recipient countries, but it also contributes to the process of development of institutional relations, in that related administrative bodies maintain contact after the completion of a given project. It is necessary to stress that the inclusion of state officials from the candidate countries as junior partners is extremely important, since they offer a direct perspective emerging from the process of transition and adjustment to the standards of the European Union. Since the twinning model can currently only be applied in certain sectors (public administration reform, justice and home affairs, public finance, and adjustment of laws related to the functioning of the internal market), it is estimated that it would be useful to extend the twinning model to the entire acquis communautaire.

Furthermore, it would be extremely helpful to undertake the necessary legal and institutional measures with a view toward harmonizing the CARDS implementation mechanism with the INTERREG initiative and other programs of cross-border cooperation open to the candidate countries (PHARE CBC). Within its priority goals, the CARDS Program includes the promotion of cross-border, trans-national, and regional cooperation among the recipient countries, and cooperation with the candidate countries and the EU member states. In Croatia, for example, there is great interest at the national and regional levels for implementing the activities that would result in closer linkages between national (regional) areas that share common borders or belong to a larger trans-national area. The majority of those activities are planned within the scope of the INTERREG initiative or bilateral cross-border cooperation with Slovenia and Hungary. The member states are entitled to utilize the resources of the European Fund for Regional Development for participation in such activities, and the candidate countries are granted this opportunity through programs supporting cross-border cooperation (PHARE Cross Border Cooperation). Croatia and other SAA countries, however, are currently not in the position to finance their participation with means provided by the CARDS Program in such a manner that the projects are mutually linked. The extension of this provision to the SAA countries would contribute a great deal to the implementation of the new assistance strategy and subsequently to the process of postconflict rehabilitation in the region. Bearing this in mind, there is an urgent need for the CARDS Program to act in a manner that is complementary to other Community initiatives and programs. In this sense, the measures necessary to adjust the implementation mechanisms of the mentioned instruments and secure appropriate financial means for the implementation of cross-border and trans-national projects should be undertaken. 


\section{Conclusion}

The EU has made increasing efforts lately to enforce its foreign policy, as well as its security policy, in order to become a more relevant partner of the U.S., at the same time contributing to the transformation of the international relations paradigm from the present state of unilateralism to multilateralism. One of the preconditions for this transformation is the creation of the sub-regional security structure in South Eastern Europe, or the Western Balkans, and the involvement of the states in the region in the process of "Eastern enlargement." Bearing in mind the armed conflicts, destruction, and bloodshed that have plagued the region in the past decade, this is a very complex task. However, a stable security situation in "Europe's backyard" (the informal nickname for the region) is one of the conditions for securing the entire territory of the EU, as well as territories beyond its formal borders. The best guarantee for this would be adjusting these countries to EU standards and criteria, which is the optimal way toward successful post-conflict rehabilitation. One of the preconditions is a suitable level of economic development, and in this context a suitable level of economic cooperation.

Here one encounters a delicate question concerning the level of such cooperation. Economic cooperation between countries with such differences in economic development, and even differences in their respective development of democratic society, could turn out to be counterproductive. The theory of integration and cooperation should be thoroughly examined. It starts with functional cooperation, goes on to functional integration, which then leads to institutional cooperation, and ends in institutional integration. It should be carefully analyzed to find out which type of cooperation could be applied to the territory of the Western Balkans in order to exercise optimal PCR practices.

According to economic indicators, there are substantial differences between the level of development of Croatia and other countries in the region. In theory (as well as in practice), these differences could be overcome only by a normal market approach, which forms the basis of all the reforms of the countries in transition. The market approach derives from the business interests of business units or companies, and not from political structures, which aim to form an association under all costs, thus forming an association with no real business interest. If Croatian companies are interested in buying certain factories in Serbia, and vice-versa, they should carry out their business transactions on their own. As far the state authorities are concerned, they could give their support to a particular type of functional cooperation. State authorities could, for instance, give their support to cooperation regarding free trade zones. Any further cooperation - whether it be in the form of multilateral free trade zones, highly recommended by Brussels, or custom unions - should be left in the hands of business experts. Therefore, this is a very delicate situation, one that requires a subtle approach from all parties involved, including Brussels and the stakeholders in the region, as well as careful decision-making.

As far as other assumptions about how best to attract foreign investments are concerned, it is very important to establish a credible judiciary and effective structures of public administration. The situation in Croatia concerning both these elements is 
catastrophic. This is the case at the level of civil and criminal lawsuits, but also regarding the procedures governing accepting foreign investments. The legal procedure regarding foreign investments is very complicated and long; cases dealing with corruption and privatization in this area are simply being postponed until the statute of limitations runs out. Even the international community has singled this out as a problem. A large part of the funds of the CARDS Program were allocated for the reform of the judiciary and public administration in Croatia. This is a cesspool that needs to be filled in order to attract more foreign investment. There are no orderly land registry books in Croatia, so when an investor asks for the exact borders of the land he has bought, no one knows. This is a vicious circle.

Generally, it can be concluded that the stabilization process in the region has made progress, but the complex and long-term challenges of state-building and economic development are far from being met. The region is not yet firmly locked into the EU integration process, and the situation in Serbia in particular could get worse before it gets better. In addition, a coming array of presidential and local elections will provide new opportunities for the radicals to further enhance their strength. The Western Balkans need the EU very much, and the EU is now offering a new assistance strategy for the region, but the level of assistance offered is insufficient (except for Croatia) to meet the main preconditions for successful post-conflict rehabilitation. 